\title{
Impact and implications of meltwater percolation on trace element records observed in a high-Alpine ice core
}

\author{
SVEN ERIK AVAK, ${ }^{1,2,3}$ MARGIT SCHWIKOWSKI, ${ }^{1,2,3}$ ANJA EICHLER ${ }^{1,3}$ \\ ${ }^{1}$ Laboratory of Environmental Chemistry, Paul Scherrer Institute, Villigen PSI, 5232, Switzerland \\ ${ }^{2}$ Department of Chemistry and Biochemistry, University of Bern, Bern, 3012, Switzerland \\ ${ }^{3}$ Oeschger Centre for Climate Change Research, University of Bern, Bern, 3012, Switzerland \\ Correspondence: Anja Eichler <anja.eichler@psi.ch>
}

\begin{abstract}
Past atmospheric pollution can be reconstructed from ice core trace element records retrieved from mountain glaciers. However, the current global temperature increase can result in post-depositional melt processes, significantly altering the originally stored information. Here, we present a comprehensive study on the behaviour of 35 trace elements (TEs) during meltwater percolation in a high-Alpine ice core segment from upper Grenzgletscher, Switzerland. Some TEs revealed significant concentration depletion, whereas others were well preserved depending on their water solubility and location at the grain scale. TEs present in insoluble minerals, typically enriched at grain boundaries, were found to be mostly preserved because their insolubility in water results in immobility with meltwater percolation. Water-soluble TEs revealed a variable meltwater-mobility. Whereas ultra-TEs tend to be preserved, likely due to incorporation into the ice lattice, abundant TEs are prone to relocation from grain-boundary regions. We propose that at Alpine sites, $\mathrm{Ag}, \mathrm{Al}, \mathrm{Bi}, \mathrm{Cu}, \mathrm{Cs}, \mathrm{Fe}, \mathrm{Li}, \mathrm{Mo}, \mathrm{Pb}, \mathrm{Rb}$, $\mathrm{Sb}, \mathrm{Th}, \mathrm{Tl}, \mathrm{U}, \mathrm{V}, \mathrm{W}, \mathrm{Zr}$ and the rare-earth elements may still be applicable as robust environmental proxies even if partial melting occurred, whereas $\mathrm{Ba}, \mathrm{Ca}, \mathrm{Cd} \mathrm{Co}, \mathrm{Mg}, \mathrm{Mn}, \mathrm{Na}, \mathrm{Ni}, \mathrm{Sr}$ and $\mathrm{Zn}$ are prone to significant depletion.
\end{abstract}

KEYWORDS: climate change, ice chemistry, ice core, mountain glaciers

\section{INTRODUCTION}

High-mountain glacier ice cores serve as invaluable environmental archives for the reconstruction of past climate and atmospheric composition. Due to their close proximity, ice core records retrieved from high-altitude glaciers and ice caps often allow to track environmental changes in the most densely populated and industrialized regions in the world. Environmental paleo records from ice cores are generally obtained through the chemical analysis of the entrapped atmospheric air, and the impurities which were transported as wet or dry deposition to the surface of a glacier and preserved in the ice over time. Among the ensemble of impurities used as reconstruction proxies, trace elements (TEs) play a substantial role. TE concentration records from highaltitude ice cores can provide a wide range of regional and global scale information such as for example on volcanism (Kaspari and others, 2009b; Kellerhals and others, 2010; Gabrielli and others, 2014), sources and variations of atmospheric mineral dust (Kaspari and others, 2009a), and in particular, historical changes of the various forms of atmospheric anthropogenic pollution (Correia and others, 2003; Hong and others, 2004; Schwikowski and others, 2004; Barbante and others, 2004; Gabrieli and others, 2011; Lee and others, 2011; Eichler and others, 2014, 2015, 2017; Uglietti and others, 2015; Grigholm and others, 2016; Eyrikh and others, 2017; Beaudon and others, 2017; SierraHernández and others, 2018).

For reconstructing past climatic and environmental changes, the use of pristine ice cores, where the multiple proxy information has not been disturbed by post-depositional processes such as melting, infiltration, and refreezing, is advantageous to ensure a reliable reconstruction (Zhang and others, 2015). For this reason, ice cores from high-altitude cold glaciers, which do not experience significant meltwater percolation between different annual layers, are the preferred objects of investigation. However, potential drilling sites are more and more difficult to find as many high-mountain glaciers worldwide are retreating or are in danger of melting (Zemp and others, 2009; Huss and others, 2017) due to the current global temperature increase (Marcott and others, 2013). To continue using ice cores from high-altitude areas as environmental archives in the future, it is crucial to understand to what extent proxy information in ice core records is altered by post-depositional melting processes.

Several studies have been addressing this issue. In the case of the stable oxygen isotope ratio $\left(\delta^{18} \mathrm{O}\right)$ the annual signal can be smoothed due to meltwater percolation making any reconstruction of past temperature impossible (Thompson and others, 1993). The major ion record can also be dramatically disturbed as detected in a $16 \mathrm{~m}$ section of an ice core from upper Grenzgletscher, Swiss Alps (Note: the same ice core investigated here) (Eichler and others, 2001). Concentration records of some major ions in this core were well preserved, but others were depleted to values close to the detection limit due to relocation with percolating meltwater. An elution sequence was postulated to explain the preferential removal of certain ionic species. Pavlova and others (2015) showed that partial melting and refreezing, a process frequently occurring in temperate glaciers, can even result in relocation and release of persistent organic pollutants, substances with low water solubility. However, the influence of meltwater percolation on TE records still remains largely unclear as there has been no systematic investigation so far. Wong and others (2013) focused on 12 
TEs associated with insoluble dust and observed that artificial meltwater infiltration in Greenland snow pits lowered TE concentrations, but in spite of that, the TE seasonality was still conserved. They concluded that especially particle bound rare-earth elements (REEs) are relatively immobile with meltwater percolation. In another study, profiles of both crustal and anthropogenic originating TEs of a snow pit from Mt. Ortles glacier, Italian Alps, did not seem to be notably altered even though significant melt events occurred during summer (Gabrieli and others, 2011).

Here, we discuss the behaviour of 35 TEs in a $50 \mathrm{~m}$ segment of an ice core from upper Grenzgletscher, Switzerland. At the centre of this segment, a $16 \mathrm{~m}$ section is located that was affected by meltwater percolation induced by a lateral meltwater inflow, presumably originating from a crevasse system. This core section consisted of firn at the time of infiltration (Eichler and others, 2001). This unique setting allows comparing the affected, and unaffected TE profiles above and below to characterize the impact of melting processes. Particular attention is given to providing an approach for explaining the observed TE patterns, and how the outcome of this study may contribute to the future interpretation of TE ice core records disturbed by meltwater percolation events.

\section{MATERIALS AND METHODS}

\subsection{Ice core characteristics, detection of meltwater percolation and dating}

The $50 \mathrm{~m}$ ice core segment investigated in this study was part of a $125 \mathrm{~m}$ long ice core recovered from upper Grenzgletscher, Monte Rosa massif, southern Swiss Alps

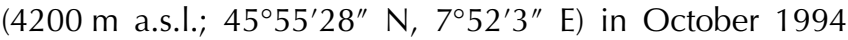
(Eichler and others, 2000a, b, 2001; Müller-Tautges and others, 2016). Continuous negative borehole temperatures indicated that the upper Grenzgletscher consists of cold firn and ice down to a depth of $125 \mathrm{~m}$. The borehole temperature profile also revealed an unusual local temperature maximum of $-1{ }^{\circ} \mathrm{C}$ at a depth of $28 \mathrm{~m}$ (18 m w.e.) (Eichler, Schwikowski, Gäggeler, and others, 2000). This maximum was attributed to a lateral inflow of meltwater at 19-20 m (11-12 m w.e.) presumably due to a crevasse system in the glacier, subsequent percolation through the underlying firn layers, partial refreezing and drainage along the former firn/ ice transition located at $\sim 35 \mathrm{~m}$ (24 m w.e.) at the time of the drilling (Eichler and others, 2001). Refreezing of meltwater generally leads to an increased ice temperature due to the release of latent heat (Schwikowski and others, 2013).

The age-depth relationship of the ice core was established by combining annual layer counting of signals with strong seasonal variations $\left(\mathrm{NH}_{4}^{+}\right.$and $\left.\delta^{18} \mathrm{O}\right)$ together with reference horizons from Saharan dust falls (1947, 1977 and 1990), atmospheric nuclear weapons tests (1950s and 60s), and the 1986 Chernobyl reactor accident (Eichler and others, 2000b). The obtained timescale was supported by nuclear dating with ${ }^{210} \mathrm{~Pb}$ and fitting a simple kinematic ice flow model through the data. The $125 \mathrm{~m}$ long ice core covered the time period of 1937-94 with a dating uncertainty of $<1$ year for the period 1970-94 and \pm 2 years for the period 1937-69.

The determined mean annual accumulation rate at the drilling site was $2.7 \mathrm{~m}$ w.e. Comparison of annual accumulation rates at the upper Grenzgletscher site and annual precipitation rates at the $50 \mathrm{~km}$ distant weather station, Col du Grand St Bernard (2469 m a.s.I., Eichler and others, 2000b; Mariani and others, 2014), indicates that the upper Grenzgletscher retains an all-year precipitation record. This is in contrast to the nearby Colle Gnifetti saddle $(1 \mathrm{~km}$ away) with strong wind erosion especially during winter (Döscher and others, 1995).

\subsection{Sample preparation and trace element analysis}

The ice core sections were stored in polyethylene tubes at $-20{ }^{\circ} \mathrm{C}$ until sample preparation. The segment between 2.2 and $52.2 \mathrm{~m}$, corresponding to the time period 1980-93, was analyzed for this study. This includes the section affected by meltwater percolation between 19 and $35 \mathrm{~m}$. This section consisted of firn when meltwater infiltration occurred (Eichler and others, 2001). The segments 13.3-14.7 m (within the year 1991) and 43.4-44.4 m (within the year 1982) could not be sampled as there was no ice remaining after previous analyses.

To remove possible contamination caused by the drilling procedure, previous sample preparation, or storage, the outer surface of the ice core sections was removed with a band saw, fitted with a Teflon-coated saw guide and tabletop, at $-20^{\circ} \mathrm{C}$ in the cold room at the Paul Scherrer Institute. In total, 550 samples with a cross-section of $\sim 1.6 \times 1.6 \mathrm{~cm}$ and lengths ranging from 4 to $15 \mathrm{~cm}$ (average of $8.3 \mathrm{~cm}$ ) were cut resulting in an average sampling resolution of 41 samples per year. Ice samples from a core depth below $20.0 \mathrm{~m}$ were rinsed with ultrapure water $(18$ $M \Omega c m$ quality, Milli-Q ${ }^{\circledR}$ Element system, Merck Millipore, Burlington MA, USA) under a class 100 laminar flow clean bench to remove the outer $\sim 0.2 \mathrm{~cm}$ containing potential contamination from the stainless steel saw blade and/or the handling. Firn samples above this depth were decontaminated by scraping all faces $(\sim 0.3 \mathrm{~cm})$ with a ceramic knife (Boker USA, Lakewood CO, USA) since rinsing was not possible due to high porosity (density $<0.7 \mathrm{~g} \mathrm{~cm}^{-3}$ ). This decontamination procedure has been well established for discrete TE analysis (Eichler and others, 2012). All decontaminated samples were transferred into polypropylene tubes (Sarstedt, Nümbrecht, Germany), which were cleaned five times with ultrapure water and once with $0.2 \mathrm{M} \mathrm{HNO}_{3}$ prepared from ultrapure $\mathrm{HNO}_{3}$ (OptimaTM, Fisher Chemical, Loughborough, UK) beforehand.

The samples were acidified with concentrated ultrapure $\mathrm{HNO}_{3}$ to $0.2 \mathrm{M}$, melted at room temperature, and analyzed using discrete inductively coupled plasma sector field mass spectrometry (ICP-SF-MS, Element 2, Thermo Fisher Scientific, Bremen, Germany). Concentrations, either in low (LR) or medium resolution (MR), of ${ }^{7} \mathrm{Li}(\mathrm{LR} \& \mathrm{MR}),{ }^{23} \mathrm{Na}$, ${ }^{24} \mathrm{Mg},{ }^{27} \mathrm{Al},{ }^{44} \mathrm{Ca},{ }^{45} \mathrm{Sc},{ }^{51} \mathrm{~V},{ }^{55} \mathrm{Mn},{ }^{56} \mathrm{Fe},{ }^{59} \mathrm{Co}$ (all MR), ${ }^{60} \mathrm{Ni},{ }^{63} \mathrm{Cu},{ }^{66} \mathrm{Zn}$ (all LR \& MR), ${ }^{85} \mathrm{Rb},{ }^{88} \mathrm{Sr},{ }^{90} \mathrm{Zr},{ }^{95} \mathrm{Mo}$ ${ }^{109} \mathrm{Ag},{ }^{111} \mathrm{Cd},{ }^{121} \mathrm{Sb},{ }^{133} \mathrm{Cs},{ }^{138} \mathrm{Ba},{ }^{139} \mathrm{La},{ }^{140} \mathrm{Ce},{ }^{141} \mathrm{Pr}$, ${ }^{146} \mathrm{Nd},{ }^{147} \mathrm{Sm},{ }^{153} \mathrm{Eu},{ }^{172} \mathrm{Yb},{ }^{182} \mathrm{~W},{ }^{205} \mathrm{Tl},{ }^{206} \mathrm{~Pb},{ }^{207} \mathrm{~Pb}$, ${ }^{208} \mathrm{~Pb},{ }^{209} \mathrm{Bi},{ }^{232} \mathrm{Th}$, and ${ }^{238} \mathrm{U}$ (all LR) were determined. A microconcentric nebulizer (apex Q, Elemental Scientific, Omaha NE, USA) together with an autosampler (CETAC ASX-260, Teledyne Cetac, Omaha NE, USA) was used for sample introduction. ${ }^{103} \mathrm{Rh}$ served as the internal standard to correct for intensity variations during sample introduction, and for plasma fluctuations. External calibration with seven different liquid calibration standards was used for quantification. Concentrations of each element in the calibration 
standards were adapted to account for their different concentrations in glacier ice. Correlation coefficients for linear regressions of the calibration curves were consistently higher than 0.999. This calibration procedure has been successfully employed in previous studies (Knüsel and others, 2003; Eichler and others, 2012, 2014, 2015, 2017).

\subsection{Data evaluation}

Raw data were evaluated following the method described by Knüsel and others (2003). Concentrations were blank-corrected by subtracting a procedural blank (Table 1). Procedural blank concentrations were determined by analysing $\sim 8 \mathrm{~cm}$ long ice sticks of frozen ultrapure water. These sticks were prepared like the ice core samples and were either decontaminated with ultrapure water or a ceramic knife as described above. The instrumental detection limit was defined as $3 \sigma$ of the measurement blank consisting of 22 measurements of ultrapure water (Table 1). Concentrations below the detection limit were substituted with half the value of the detection limit. A reduced dataset consisting of equidistant data points was created out of the blank-corrected dataset for each TE by calculating average concentration values for each month within the time period 1980-93 covered by the investigated ice core segment, assuming homogeneous precipitation distribution throughout the year (or equal binning).

\section{RESULTS AND DISCUSSION}

\subsection{Data presentation and characterisation}

Ice core concentration records of selected TEs (Ag, Cd, Cs, Eu, $\mathrm{Na}, \mathrm{Pb}, \mathrm{Tl})$ covering the period 1980-93 are shown in Figure 1 . The entire ice core was previously analyzed for the main soluble inorganic cations and anions using ion chromatography (IC) (Eichler and others, 2000b, 2001). Thus, concentrations of $\mathrm{Na}, \mathrm{Mg}$ and $\mathrm{Ca}$ have been determined by two independent analytical methods and can, therefore, be used to assess the reproducibility and representativeness of the data. Our measurements of $\mathrm{Ca}, \mathrm{Na}$ and $\mathrm{Mg}$ concentrations agree well with the concentration records obtained by IC. For example, the $\mathrm{Na}^{+}$and the $\mathrm{Na}$ concentration profiles (Fig. 1) reveal a strong correspondence between each other $\left(R^{2}=0.81\right) \quad$ despite different sampling and analytical methods, and the long-term storage between the two studies.

In general, concentration records of all 35 TEs reveal a very distinct seasonal pattern with high summer and low winter concentrations. This seasonality, typical for highAlpine sites, is the result of stronger convection in summer allowing polluted air masses from the planetary boundary layer to reach the high-altitude sites of the Alps, while in winter, they are decoupled from the underlying air masses (Baltensperger and others, 1997). The pronounced seasonal variability is also visible in the record of water stable isotopes $\left(\delta^{18} \mathrm{O}\right)$, in line with temperature data from the nearby weather station Col du Grand St. Bernard (Eichler and others, 2001; Mariani and others, 2014, Fig. 1). Depending on the identifiability of the seasonal pattern within the meltwateraffected period 1985-89, the investigated 35 TEs were split into two groups. TEs of group 1, including $\mathrm{Ag}, \mathrm{Al}, \mathrm{Bi}, \mathrm{Ce}$, $\mathrm{Cs}, \mathrm{Cu}, \mathrm{Eu}, \mathrm{Fe}, \mathrm{La}, \mathrm{Li}, \mathrm{Mo}, \mathrm{Nd}, \mathrm{Pb}, \mathrm{Pr}, \mathrm{Rb}, \mathrm{Sb}, \mathrm{Sc}, \mathrm{Sm}, \mathrm{Tl}$, $\mathrm{Th}, \mathrm{U}, \mathrm{V}, \mathrm{W}, \mathrm{Yb}$ and $\mathrm{Zr}$, keep their seasonal concentration pattern. Group $2 \mathrm{TEs}$, comprising $\mathrm{Ba}, \mathrm{Ca}, \mathrm{Cd}, \mathrm{Co}, \mathrm{Mg}, \mathrm{Mn}$, $\mathrm{Na}, \mathrm{Ni}, \mathrm{Sr}$ and $\mathrm{Zn}$, are significantly depleted and no

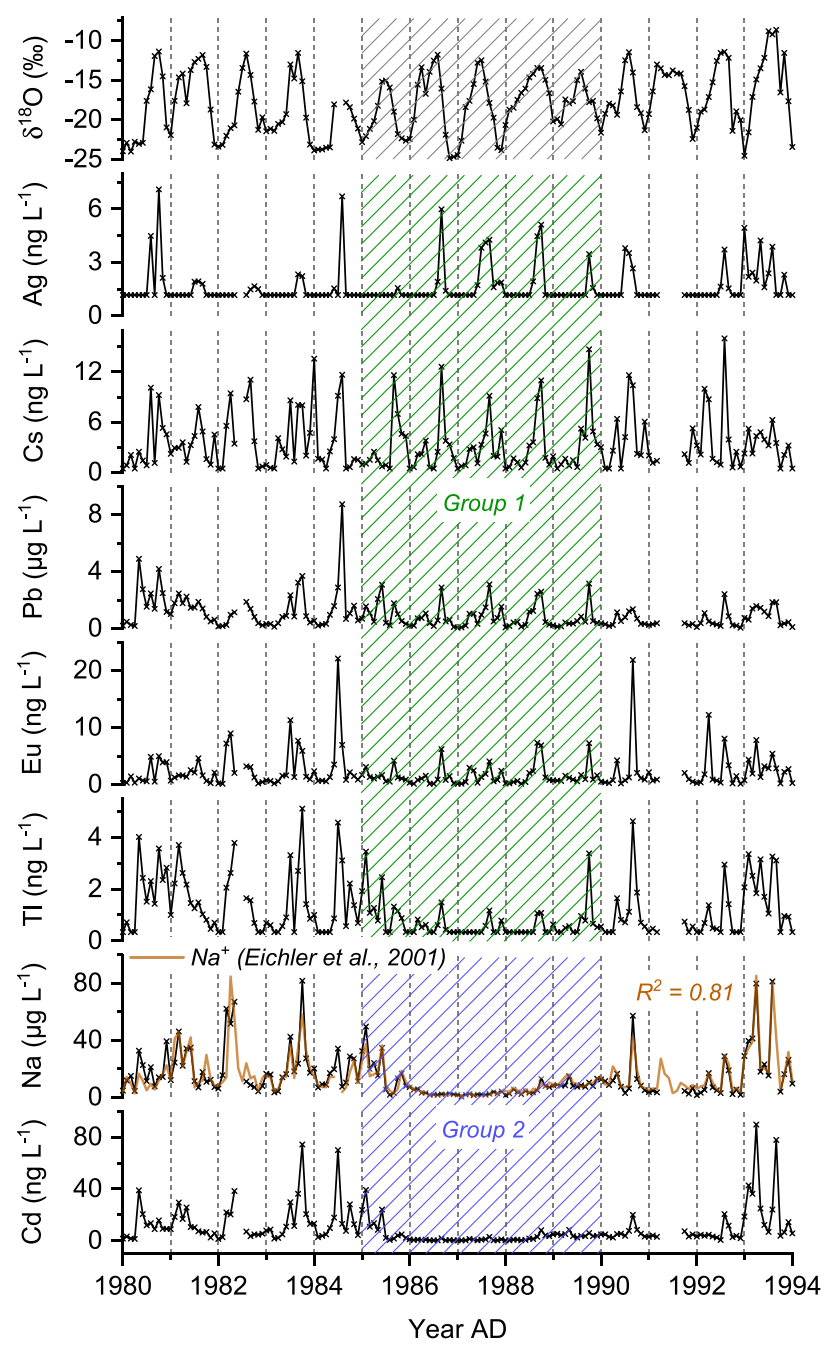

Fig. 1. Monthly mean concentration records of $\mathrm{Ag}, \mathrm{Cs}, \mathrm{Pb}, \mathrm{Eu}, \mathrm{Tl}$, $\mathrm{Na}$ and $\mathrm{Cd}$ representing group 1 and 2 TEs and covering the period 1980-93 corresponding to the ice core segment from upper Grenzgletscher analyzed and discussed in this study. For comparison, the $\delta^{18} \mathrm{O}$ and the $\mathrm{Na}^{+}$records reported by Eichler and others (2001) are shown. The shaded area (1985-89) indicates the section affected by meltwater percolation.

seasonality can be identified. This is exemplarily shown in Figure 1 with $\mathrm{Ag}, \mathrm{Cs}, \mathrm{Eu}, \mathrm{Tl}, \mathrm{Pb}$ for group $1 \mathrm{TEs}$ and $\mathrm{Cd}, \mathrm{Na}$ representing group 2 TEs.

These observed anomalies within the time period 198589 coincide with the observations of ion fractionation made by Eichler and others (2001). In their study, they postulated that meltwater percolated through the firn layers at the time of infiltration, primarily along the grain surfaces, removing impurities by drainage at the firn/ice transition. We suggest that the same process caused the disturbed and depleted concentration profiles of some TEs. Apparently, TEs were removed with different efficiencies; while some were almost completely depleted, others were not affected or only affected to a minor degree.

\subsection{Quantification of concentration depletion in the meltwater-influenced section}

To quantify and directly compare the different behaviour of the 35 TEs, a ratio between the mean concentration of the meltwater-affected section (1986-88) and the unaffected 
Table 1. Detection limits (DLs), procedural blank concentrations* of the discrete ICP-SF-MS analysis, concentration ratios between the mean concentration of the meltwater-affected section and the unaffected sections, mean concentrations within the unaffected part of the ice core segment (time periods 1980-84 and 1990-92) ${ }^{\dagger}$, ionic radii in aqueous solution ${ }^{\ddagger}$ and hydrated radii ${ }^{\S}$ of the investigated TEs. Where more than one oxidation state is stated, the mean of the respective radii is listed.

\begin{tabular}{|c|c|c|c|c|c|c|c|}
\hline $\mathrm{TE}$ & $\begin{array}{c}\mathrm{DL} \\
\left(n \mathrm{ng} \mathrm{L}^{-1}\right)\end{array}$ & $\begin{array}{l}\text { Procedural blank } \\
\text { ultrapure water" } \\
\quad\left(\mathrm{ng} \mathrm{L}^{-1}\right)\end{array}$ & $\begin{array}{l}\text { Procedural blank } \\
\text { ceramic knife } \\
\quad\left(n g L^{-1}\right)\end{array}$ & $\begin{array}{c}\text { Concentration } \\
\text { ratio }\end{array}$ & $\begin{array}{l}\text { Mean concentration in } \\
\text { unaffected part }\left(\mathrm{ng} \mathrm{L}^{-1}\right)\end{array}$ & $\begin{array}{l}\text { Ionic radius in } \\
\text { aqueous solution } \\
(\mathrm{pm})\end{array}$ & $\begin{array}{l}\text { Hydrated } \\
\text { radius }(\mathrm{pm})\end{array}$ \\
\hline $\mathrm{Ag}$ & 2.3 & $<\mathrm{DL}$ & $<\mathrm{DL}$ & $1.2 \pm 0.23$ & $1.5 \pm 0.11$ & $115\left(\mathrm{Ag}^{+}\right)$ & $341\left(\mathrm{Ag}^{+}\right)$ \\
\hline $\mathrm{Al}$ & 206 & $394 \pm 406$ & $<\mathrm{DL}$ & $0.69 \pm 0.22$ & $18700 \pm 2800$ & $53\left(\mathrm{Al}^{3+}\right)$ & $475\left(\mathrm{Al}^{3+}\right)$ \\
\hline $\mathrm{Ba}$ & 5.2 & $<\mathrm{DL}$ & $15 \pm 5.9$ & $0.25 \pm 0.08$ & $583 \pm 88$ & $136\left(\mathrm{Ba}^{2+}\right)$ & $404\left(\mathrm{Ba}^{2+}\right)$ \\
\hline $\mathrm{Bi}$ & 1.7 & $<\mathrm{DL}$ & $<\mathrm{DL}$ & $0.98 \pm 0.35$ & $2.6 \pm 0.42$ & $102\left(\mathrm{Bi}^{3+}\right)$ & - \\
\hline $\mathrm{Cd}$ & 0.42 & $<\mathrm{DL}$ & $<\mathrm{DL}$ & $0.11 \pm 0.04$ & $11 \pm 1.4$ & $95\left(\mathrm{Cd}^{2+}\right)$ & $426\left(\mathrm{Cd}^{2+}\right)$ \\
\hline $\mathrm{Ce}$ & 0.07 & $0.22 \pm 0.27$ & $0.25 \pm 0.16$ & $0.71 \pm 0.27$ & $89 \pm 15$ & $101\left(\mathrm{Ce}^{3+}\right)$ & $452\left(\mathrm{Ce}^{3+}\right)$ \\
\hline Co & 0.33 & $<\mathrm{DL}$ & $<\mathrm{DL}$ & $0.21 \pm 0.06$ & $21 \pm 2.8$ & $70\left(\mathrm{Co}^{2+/ 3+}\right)$ & $423\left(\mathrm{Co}^{2+}\right)$ \\
\hline $\mathrm{Cs}$ & 0.90 & $<\mathrm{DL}$ & $<\mathrm{DL}$ & $0.77 \pm 0.21$ & $3.7 \pm 0.38$ & $170\left(\mathrm{Cs}^{+}\right)$ & $329\left(\mathrm{Cs}^{+}\right)$ \\
\hline $\mathrm{Cu}$ & 13 & $<\mathrm{DL}$ & $20 \pm 0.53$ & $0.71 \pm 0.19$ & $111 \pm 12$ & $73\left(\mathrm{Cu}^{2+}\right)$ & $419\left(\mathrm{Cu}^{2+}\right)$ \\
\hline $\mathrm{Eu}$ & 0.21 & $<\mathrm{DL}$ & $<\mathrm{DL}$ & $0.60 \pm 0.23$ & $2.5 \pm 0.41$ & $95\left(\mathrm{Eu}^{3+}\right)$ & $465\left(\mathrm{Eu}^{3+}\right)$ \\
\hline $\mathrm{Fe}$ & 351 & $<\mathrm{DL}$ & $636 \pm 598$ & $0.75 \pm 0.22$ & $11300 \pm 1430$ & $72\left(\mathrm{Fe}^{2+/ 3+}\right)$ & $442.5\left(\mathrm{Fe}^{2+/ 3+}\right)$ \\
\hline $\mathrm{Li}$ & 11 & $<\mathrm{DL}$ & $<\mathrm{DL}$ & $0.54 \pm 0.12$ & $18 \pm 1.8$ & $69\left(\mathrm{Li}^{+}\right)$ & $382\left(\mathrm{Li}^{+}\right)$ \\
\hline $\mathrm{Mg}$ & 77 & $89 \pm 68$ & $355 \pm 109$ & $0.26 \pm 0.10$ & $15900 \pm 3800$ & $72\left(\mathrm{Mg}^{2+}\right)$ & $428\left(\mathrm{Mg}^{2+}\right)$ \\
\hline $\mathrm{Mn}$ & 2.7 & $<\mathrm{DL}$ & $7.1 \pm 2.2$ & $0.13 \pm 0.04$ & $1250 \pm 171$ & $83\left(\mathrm{Mn}^{2+}\right)$ & $438\left(\mathrm{Mn}^{2+}\right)$ \\
\hline Mo & 2.5 & $<\mathrm{DL}$ & $<\mathrm{DL}$ & $0.60 \pm 0.17$ & $8.0 \pm 0.79$ & - & - \\
\hline $\mathrm{Na}$ & 446 & $<\mathrm{DL}$ & $1030 \pm 651$ & $0.22 \pm 0.05$ & $16400 \pm 1650$ & $102\left(\mathrm{Na}^{+}\right)$ & $358\left(\mathrm{Na}^{+}\right)$ \\
\hline $\mathrm{Nd}$ & 0.06 & $0.09 \pm 0.11$ & $0.08 \pm 0.06$ & $0.67 \pm 0.26$ & $49 \pm 8.3$ & $99\left(\mathrm{Nd}^{3+}\right)$ & $461\left(\mathrm{Nd}^{3+}\right)$ \\
\hline $\mathrm{Ni}$ & 3.8 & $4.4 \pm 7.7$ & $6.1 \pm 6.1$ & $0.21 \pm 0.06$ & $77 \pm 6.6$ & $69\left(\mathrm{Ni}^{2+}\right)$ & $404\left(\mathrm{Ni}^{2+}\right)$ \\
\hline $\mathrm{Pb}$ & 48 & $<\mathrm{DL}$ & $<\mathrm{DL}$ & $0.73 \pm 0.22$ & $1080 \pm 139$ & $118\left(\mathrm{~Pb}^{2+}\right)$ & $401\left(\mathrm{~Pb}^{2+}\right)$ \\
\hline $\operatorname{Pr}$ & 0.07 & $<\mathrm{DL}$ & $<\mathrm{DL}$ & $0.69 \pm 0.27$ & $12 \pm 2.0$ & $100\left(\operatorname{Pr}^{3+}\right)$ & $461\left(\operatorname{Pr}^{3+}\right)$ \\
\hline $\mathrm{Rb}$ & 1.5 & $<\mathrm{DL}$ & $<\mathrm{DL}$ & $0.49 \pm 0.13$ & $46 \pm 4.9$ & $149\left(\mathrm{Rb}^{+}\right)$ & $329\left(\mathrm{Rb}^{+}\right)$ \\
\hline $\mathrm{Sb}$ & 1.6 & $<\mathrm{DL}$ & $<\mathrm{DL}$ & $0.79 \pm 0.23$ & $7.8 \pm 0.77$ & $77\left(\mathrm{Sb}^{3+}\right)$ & - \\
\hline Sc & 0.51 & $<\mathrm{DL}$ & $<\mathrm{DL}$ & $0.65 \pm 0.21$ & $3.0 \pm 0.41$ & $75\left(\mathrm{Sc}^{3+}\right)$ & - \\
\hline $\mathrm{Sm}$ & 0.07 & $<\mathrm{DL}$ & $<\mathrm{DL}$ & $0.65 \pm 0.25$ & $10 \pm 1.8$ & $96\left(\mathrm{Sm}^{3+}\right)$ & $462\left(\mathrm{Sm}^{3+}\right)$ \\
\hline $\mathrm{Sr}$ & 5.5 & $6.6 \pm 9.0$ & $5.8 \pm 1.5$ & $0.18 \pm 0.06$ & $599 \pm 90$ & $113\left(\mathrm{Sr}^{2+}\right)$ & $412\left(\mathrm{Sr}^{2+}\right)$ \\
\hline Th & 1.1 & $<\mathrm{DL}$ & $<\mathrm{DL}$ & $0.59 \pm 0.20$ & $5.0 \pm 0.63$ & $100\left(\mathrm{Th}^{4+}\right)$ & - \\
\hline $\mathrm{Tl}$ & 0.68 & $<\mathrm{DL}$ & $<\mathrm{DL}$ & $0.38 \pm 0.07$ & $1.3 \pm 0.13$ & $150\left(\mathrm{Tl}^{+}\right)$ & $330\left(\mathrm{Tl}^{+}\right)$ \\
\hline W & 1.7 & $<\mathrm{DL}$ & $<\mathrm{DL}$ & $0.98 \pm 0.25$ & $1.4 \pm 0.13$ & - & - \\
\hline $\mathrm{Yb}$ & 0.05 & $<\mathrm{DL}$ & $<\mathrm{DL}$ & $0.61 \pm 0.22$ & $2.4 \pm 0.40$ & $87\left(\mathrm{Yb}^{3+}\right)$ & $475\left(\mathrm{Yb}^{3+}\right)$ \\
\hline $\mathrm{Zn}$ & 67 & $74 \pm 62$ & $76 \pm 31$ & $0.26 \pm 0.07$ & $868 \pm 108$ & $75\left(\mathrm{Zn}^{2+}\right)$ & $430\left(\mathrm{Zn}^{2+}\right)$ \\
\hline $\mathrm{Zr}$ & 10 & $<\mathrm{DL}$ & $<\mathrm{DL}$ & $0.57 \pm 0.12$ & $12 \pm 1.5$ & $72\left(\mathrm{Zr}^{4+}\right)$ & - \\
\hline
\end{tabular}

\footnotetext{
* Errors given correspond to $1 \sigma$.

† Standard errors are given.

\$ Values from Marcus (2015).

$\S$ Values from Nightingale (1959) or David and others (2001).

\| Procedural blank including decontamination by rinsing samples with ultrapure water.

\# Procedural blank including decontamination by scraping all sample faces with a ceramic knife.
}

sections (1980-84 and 1990-92) was calculated for each TE (Table 1). The transition periods, corresponding to the years 1985 and 1989, and the year 1993 were not included in this analysis. The latter showed exceptional elevated summer values for many TEs compared with the previous years. The closer the concentration ratio for a certain TE is to one, the less affected the record in the meltwaterinfluenced section is. Correspondingly, the closer the ratio is to zero, the more affected the record is. In addition to the influence of meltwater percolation, the concentration ratio can be impacted by changes in atmospheric TE emissions or by changes in the transport of TEs from the emission sources to the high-Alpine sites. For example, the Pb concentration record reveals preserved seasonal variations, but also shows an overall slight decreasing trend (Fig. 1), which is due to declining anthropogenic $\mathrm{Pb}$ emissions since the 1970s (Schwikowski and others, 2004). Regarding possible changes in transport, the similar seasonal cycles of Cs concentrations during the period 1980-93 indicate a nearly constant dust input to this high-Alpine site. Thus, we assume that among those three factors that can have an influence on the concentration ratio, meltwater-induced relocation processes are dominant and outweigh possible changes in emissions or transport dynamics, especially, on such a short timescale as discussed here. All TEs had ratios between zero and one, except for $\mathrm{Ag}(1.22 \pm 0.23)$ (Table 1). Concentrations of $\mathrm{Ag}$ are to a large extent below the detection limit (Fig. 1, Table 1) and the annual summer maxima within the meltwater-influenced section are more pronounced probably due to elevated emissions in the period 1985-89.

A rank of preservation was established by arranging all TEs in ascending order according to their concentration ratio. This qualitatively shows the relative degree of impact of meltwater percolation on the different TEs within the affected 
section. The rank of preservation plotted against the concentration ratio (Fig. 2) demonstrates the impact observed for the 35 TEs and their distinct fractionation after meltwater percolation. Ca shows the strongest depletion, whereas Ag is the least depleted. Group 1 TEs possess a ratio between $0.38 \pm 0.07(\mathrm{Tl})$ and $1.22 \pm 0.23(\mathrm{Ag})$ occupying ranks of preservation 1-25, while group 2 TEs have ratios between $0.08 \pm 0.02(\mathrm{Ca})$ and $0.26 \pm 0.07(\mathrm{Zn})$, corresponding to the ranks $26-35$. The steady decline of the concentration ratios indicates a preferential elution of TEs after meltwater percolation.

\subsection{Causes for preferential elution of TEs}

A fractionation of water-soluble major ions was already observed by Eichler and others (2001) within the section of this ice core that consisted of firn when meltwater percolation occurred. $\mathrm{K}^{+}, \mathrm{Na}^{+}, \mathrm{Mg}^{2+}, \mathrm{Ca}^{2+}$ and $\mathrm{SO}_{4}^{2-}$ were substantially depleted, whereas $\mathrm{NH}_{4}^{+}, \mathrm{F}^{-}, \mathrm{Cl}^{-}$and $\mathrm{NO}_{3}^{-}$showed a well-preserved seasonality. A separation of $\mathrm{Na}^{+}$and $\mathrm{Cl}^{-}$of the initial deposited sea salt aerosol particle supported their conclusion that the different leaching efficiencies were not predominantly caused by precipitation formation or atmospheric scavenging processes. Rather, the different efficiencies were the result of post-depositional rearrangement processes during snow metamorphism causing a redistribution of chemical species according to their solubility in ice. The incorporation of $\mathrm{NH}_{4}^{+}, \mathrm{F}^{-}, \mathrm{Cl}^{-}$and $\mathrm{NO}_{3}^{-}$into the ice lattice led to their relative immobility with meltwater percolation. On the contrary, $\mathrm{K}^{+}, \mathrm{Na}^{+}, \mathrm{Mg}^{2+}, \mathrm{Ca}^{2+}$ and $\mathrm{SO}_{4}^{2-}$, which have lower solubility in ice, were excluded to grain boundaries where they were more prone to being removed. The assumption that meltwater only percolated along grain surfaces in the firn layers and did not affect the interior of the crystals is corroborated by the completely preserved $\delta^{18} \mathrm{O}$ record (Eichler and others, 2001, Fig. 1).

We assume that post-depositional snow metamorphism significantly affects the spatial distribution of TEs in snow, firn and ice. Snow metamorphism involves water vapor fluxes which can lead to a mass turnover of up to $60 \%$ of the entire ice mass per day inducing changes in the snow microstructure (Pinzer and others, 2012). During snow metamorphism, initially deposited snowflakes are transformed by continuous sublimation/evaporation and subsequent condensation processes into firn grains, since larger grains grow at the expense of smaller ones (Davis, 1991). The rearrangement of TEs within the ice structure during grain growth depends on two properties: (1) the water solubility of the TE or its compounds (e.g. water-insoluble dust particles vs. soluble sea salt aerosols) and (2) their solubility in ice. These factors determine their incorporation in glacier ice and are discussed in the following section considering also the major sources of the investigated TEs.

\subsection{Incorporation of TEs into glacier ice}

Among the set of 35 TEs discussed in this study, the majority are of geogenic origin deposited with mineral dust: $\mathrm{Al}, \mathrm{Ba}, \mathrm{Bi}$, $\mathrm{Ca}, \mathrm{Cs}, \mathrm{Fe}, \mathrm{Li}, \mathrm{Mg}, \mathrm{Mn}, \mathrm{Na}, \mathrm{Rb}, \mathrm{Sr}, \mathrm{Th}, \mathrm{Tl}, \mathrm{U}, \mathrm{W}, \mathrm{Zr}$ and the REEs (Ce, Eu, La, Nd, Pr, Sc, Sm, Yb) (Gabrielli and others, 2008; Gabrieli and others, 2011). About two-thirds of the mineral dust at the nearby Colle Gnifetti site originate from the Saharan desert (Wagenbach and Geis, 1989). In Alpine ice cores, $\mathrm{Na}$ does not only reflect contributions from

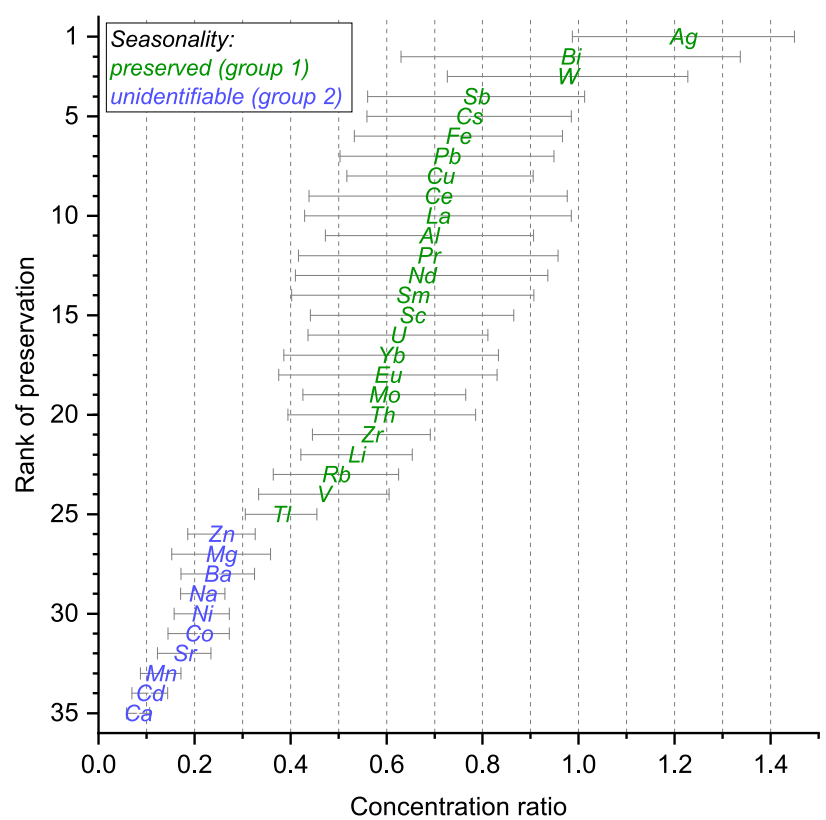

Fig. 2. Rank of preservation plotted against the concentration ratio for each TE. The concentration ratio is defined as the ratio between the mean concentration of the meltwater-affected section (1986-88) and the unaffected sections (1980-84 and 1990-92). Colour coding of the symbols indicates whether a TE kept its seasonal concentration pattern (group 1) or shows a significant depletion and no seasonality can be identified (group 2) within the section affected by meltwater percolation.

mineral dust but also contributions from marine sea salt aerosols (Eichler and others, 2004). Anthropogenic atmospheric pollution is represented by elevated concentrations of $\mathrm{Ag}$, $\mathrm{Cd}, \mathrm{Co}, \mathrm{Cu}, \mathrm{Mo}, \mathrm{Ni}, \mathrm{Pb}, \mathrm{Sb}, \mathrm{V}$ and $\mathrm{Zn}$ at alpine sites (Van de Velde and others, 1999, 2000; Barbante and others, 2004; Schwikowski and others, 2004; Gabrielli and others, 2008; Gabrieli and others, 2011). Nevertheless, those TEs can also be, to a minor extent, of mineral dust origin. In addition, $\mathrm{Bi}, \mathrm{Cd}$ and $\mathrm{Tl}$ can be tracers for volcanism (Kaspari and others, 2009a; Kellerhals and others, 2010; Gabrielli and others, 2014).

In the atmosphere, aerosol particles comprising TEs can be incorporated into the core of snow crystals by acting as ice nuclei as it is known for mineral dust aerosols (Szyrmer and Zawadzki, 1997). Accumulation of supercooled water droplets onto ice crystal surfaces (riming) or direct impaction of aerosol particles on snow crystals usually results in the enrichment of impurities at the edges of the crystal (Mosimann and others, 1994; Pruppacher and Klett, 2010). As explained above, we suggest that these processes play a minor role in determining the final location of TEs in ice. The location is predominantly determined by the effect of snow metamorphism.

\subsubsection{Water-insoluble TEs}

$\mathrm{Al}, \mathrm{Fe}, \mathrm{Zr}$ and the REEs likely originated from water-insoluble mineral dust as particles containing these TEs typically reveal a water solubility of $<10 \%$ (Greaves and others, 1994; Birmili and others, 2006; Hsu and others, 2010; Li and others, 2015). Those particles are most likely enriched at grain boundaries during snow metamorphism, even if initially deposited as condensation nuclei in the snow grain interior. Such an enrichment of Fe and $\mathrm{Al}$ was shown for 
clear bands in Greenland ice (Della Lunga and others, 2014). Although enriched on grain surfaces, their insolubility in water results in immobility with meltwater, explaining the retention of their seasonality within the section affected by meltwater percolation (Fig. 2). This interpretation is in agreement with the work performed by Wong and others (2013), where artificial meltwater infiltration in Greenland snowpack showed that, in particular, REEs are relatively immobile during meltwater percolation, and tend to keep their seasonally varying signal.

\subsubsection{Partially water-soluble TEs}

Compounds exhibiting low water solubility like terrestrial $\mathrm{Ba}$, $\mathrm{Ca}$, or $\mathrm{Mg}$ sulphate and carbonate salts are present as ions below their solubility limit. Compounds featuring high water solubility like salts of alkali metals (Cs, Na, Li, Rb) predominantly occur as ions in snow and ice. These ions can be either incorporated into the ice lattice or segregated to grain boundaries during snow metamorphism.

lons might be incorporated into the ice lattice following two different mechanisms. First, they can substitute water molecules located on lattice sites as suggested for $\mathrm{NH}_{4}^{+}, \mathrm{F}^{-}$, $\mathrm{Cl}^{-}$and $\mathrm{NO}_{3}^{-}$(Zaromb and Brill, 1956; Eichler and others, 2001; Petrenko and Whitworth, 2002). To be incorporated into the ice lattice site without significant additional strain, chemical impurities need to be of similar size and type as the oxygen atom of the water molecule to be substituted (Wolff, 1996). The more similar in size dopants are compared to that of a water molecule (diameter $2.75 \AA$ ), the more likely is substitution on lattice sites (Hobbs, 1974). Second, impurities can also occupy interstitial sites as proposed for $\mathrm{K}^{+}$regarding the incorporation of $\mathrm{KOH}$ in the ice lattice (Petrenko and Whitworth, 2002). Hexagonal ice $I_{h}$ possesses two kinds of interstices denoted as capped trigonal (Tc) and uncapped trigonal site (Tu). The Tu site (Fig. 3), which features a distance between its centre and the edges of $2.95 \AA$, has been shown to be a more stable host for interstitial species such as water molecules (Itoh and others, 1996).

Hereafter, we discuss factors possibly influencing whether TEs associated with (low) water-soluble compounds are incorporated into the ice lattice or segregated to grain boundaries. Our analysis reveals that the concentration and the atomic mass of TEs appear to have a major effect whereas TE size does not seem to play a role.

3.4.2.1. Influence of trace element size. For examining the influence of atomic size on the two possible ways of incorporation in ice (occupation of Tu interstitial space or a lattice site), we assumed that TEs originating from (low) water-soluble compounds are present as ions. Accordingly, we investigated the relationship between the concentration ratios of the TEs and the corresponding ionic radii in aqueous solution as well as the hydrated ionic radii (Table 1, Fig. 3). No significant correlation $\left(R^{2}<0.05\right)$ was found either between the hydrated or the ionic radii in aqueous solution and the concentration ratio, even after removing $\mathrm{Al}, \mathrm{Fe}, \mathrm{Zr}$ and the REEs primarily not present as ions but insoluble particles (Fig. 3). There is also no evident dependency between the concentration ratio and the distribution of the ionic radii in aqueous solution around the radius of a water molecule; TEs having a similar ionic radius as the water molecule such as $\mathrm{Ba}, \mathrm{Rb}, \mathrm{Tl}$ do not have the highest concentration ratios. Except for $\mathrm{Cs}, \mathrm{Rb}$ and $\mathrm{TI}$, all other $\mathrm{TEs}$ have smaller ionic radii than that of the water molecule suggesting that they could substitute water molecules on lattice sites. Concerning a possible occupation of the Tu interstitial site, it appears that the ionic radii are invariably smaller than the distance between the centre and the edges of the Tu interstitial site. This means that all

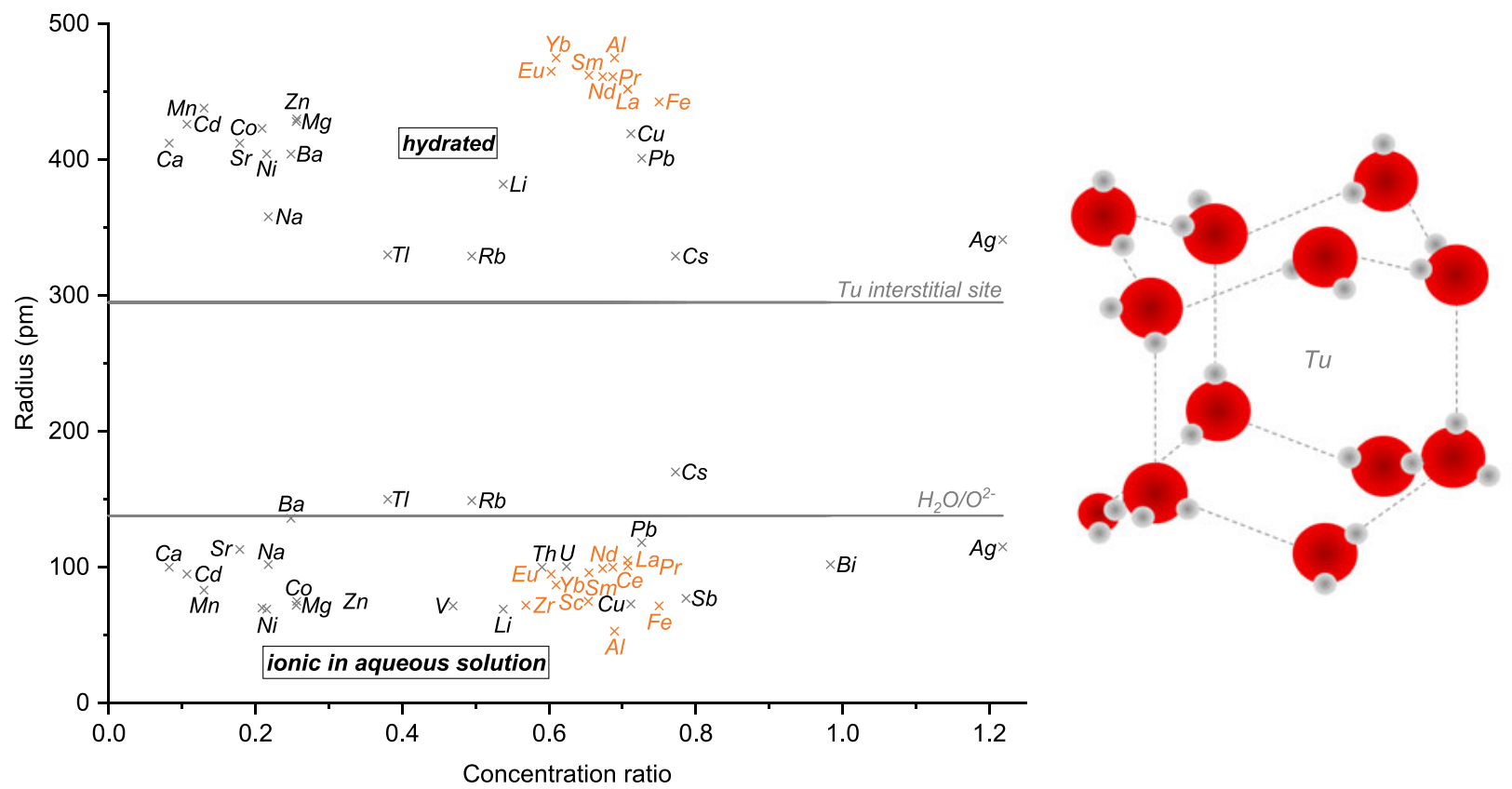

Fig. 3. Left: Hydrated and ionic radii in aqueous solution (Table 1) plotted against the concentration ratio of the corresponding TEs. Data points shown in orange represent TEs which are most likely not present as ions but rather as insoluble compounds. The radius of a water molecule and the distance between the centre and the edges of the uncapped trigonal (Tu) interstitial site in ice $I_{h}$, likely to host interstitials, are depicted as horizontal lines. Right: Sketch of the Tu site (adapted from Itoh and others, 1996). Oxygen and hydrogen atoms are shown as red and grey spheres, respectively. 
TEs could be incorporated interstitially if present as ions. In contrast, hydrated ionic radii of all TEs are significantly larger than the radius of the Tu site implying that incorporation with a hydration shell is unlikely. Our results suggest that although almost all TEs could substitute a water molecule or be interstitially incorporated into the ice lattice if present as ions, the size of TEs is not the controlling factor affecting their preservation in the presence of meltwater.

\subsubsection{Influence of trace element concentrations} and atomic mass. One fundamental property of a TE in glacier ice is the average concentration it exhibits; this generally reflects the corresponding atmospheric concentration levels (Kaspari and others, 2009b). Concentrations of TEs can be largely site-specific, such as mineral dust related TEs (Beaudon and others, 2017). Here, the mean concentrations of each TE within the two unaffected parts of the ice core segment (1980-84 and 1990-92, Table 1) were assumed to be representative of an ice core segment where no meltwater percolation took place. This assumption is justified because mean TE concentrations in ice cores from the nearby Colle Gnifetti saddle (Barbante and others, 2004; Schwikowski and others, 2004; Gabrieli, 2008), the Dôme de Goûter, Mont Blanc Massif (Barbante and others, 1999) and from a snow pit from Alto dell'Ortles glacier located in the Eastern European Alps (Gabrieli and others, 2011) are largely within the same orders of magnitude. Nevertheless, it should be noted that these reported mean concentrations do not cover exactly the same time period.

Figure 4 shows the mean concentration for each TE (logarithmic scale) plotted against the respective concentration ratio together with an exponential fit. A significant negative correlation $\left(R^{2}=0.25\right)$ was observed indicating that TEs occurring in low concentration tend to have higher concentration ratios whereas TEs with higher concentrations are mostly associated with low concentration ratios. This trend becomes even more pronounced if the TEs associated with insoluble particles (AI,
Fe, Zr, REEs) are excluded $\left(R^{2}=0.41\right)$. Based on these results, we suggest that atmospheric concentration levels are a major driving force determining whether TEs originating from (low) soluble compounds are incorporated into the ice lattice or segregated to the grain surfaces. Abundant TEs such as $\mathrm{Ca}, \mathrm{Mg}$, $\mathrm{Mn}, \mathrm{Na}$, or $\mathrm{Zn}$ are likely to be segregated to the grain boundaries, since their concentrations exceed solubility limits in ice, and are thus prone to relocation by meltwater. TEs present in ultra-trace amounts including $\mathrm{Ag}, \mathrm{Bi}, \mathrm{Cs}, \mathrm{Sb}$, or $\mathrm{W}$ tend to be incorporated into the ice lattice as indicated by a strong preservation of these TEs in the meltwater-affected section.

A significant correlation coefficient of $R^{2}=0.18$ was obtained for a linear fit between the atomic mass of the measured isotopes and the concentration ratio (Fig. 4). The fact that heavier TEs tend to be related to higher concentration ratios is presumably linked to the dependence between the average concentration in ice and the atomic mass. The average concentration in glacier ice serves as an indicator for the atmospheric concentration level, which is by itself connected to the overall abundance of a TE. Abundant TEs significantly contributing to the composition of the Earth's crust generally possess lower masses compared with the ones with higher masses that are rarer (Allègre and others, 2001). Like the mean concentration, the correlation becomes stronger $\left(R^{2}=0.24\right)$ if TEs related to insoluble particles are excluded.

Our analysis showed that TEs originating from (low) watersoluble compounds present in ultra-trace amounts and characterized by large atomic masses tend to be preserved, while no influence regarding the size of TEs could be identified. TEs related to mineral dust particles are likely to be enriched at grain boundaries, but resistant to meltwater percolation due to water insolubility.

\subsection{Implications}

This study advances the understanding of TE preservation patterns in ice cores from glaciers partially affected by
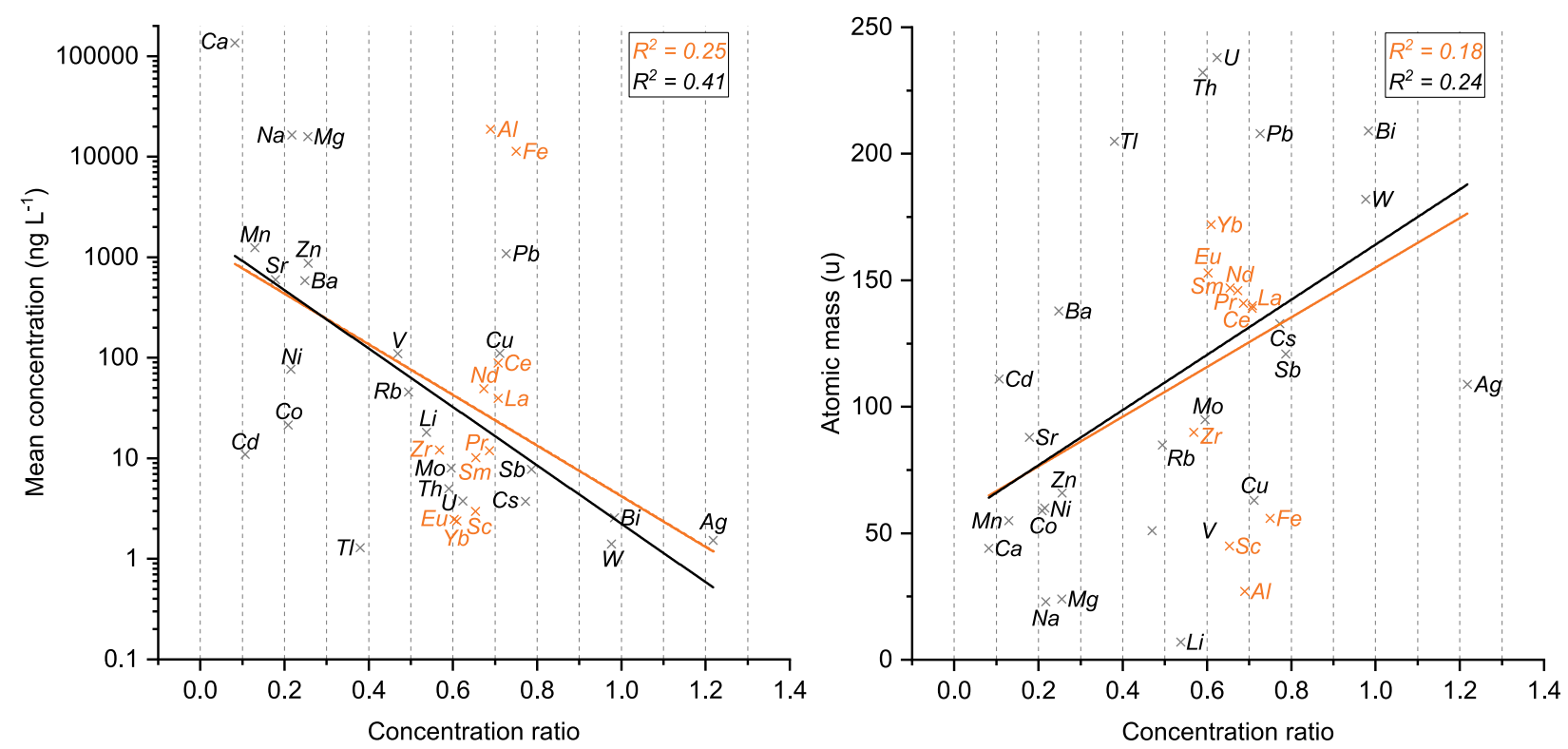

Fig. 4. Left: Mean concentration within the unaffected part of the ice core segment (logarithmic axis, time periods 1980-84 and 1990-92, Table 1) plotted against the concentration ratio of each TE. Right: Atomic mass of the measured isotopes (data from Rumble, 2017) plotted against the concentration ratio of each TE. The orange lines represent an exponential (left) and a linear fit (right), respectively including all 35 TEs (corresponding correlation coefficients in orange). The black lines represent the fit excluding $\mathrm{Al}, \mathrm{Fe}, \mathrm{Zr}$ and the REEs (corresponding correlation coefficients in black). 
melting. This is necessary for evaluating the potential of TEs as environmental proxies, especially for future interpretation of paleo atmospheric TE ice core records from high-mountain glaciers. High-mountain glaciers are increasingly prone to melt processes even in the highest accumulation areas (Zhang and others, 2015).

Among the set of TEs contained in mineral dust, $\mathrm{Al}, \mathrm{Bi}, \mathrm{Cs}$, Fe, Li, Rb, Th, Tl, U, W, Zr and the REEs (Ce, Eu, La, Nd, Pr, Sc, Sm, Yb) stand out at the investigated high-Alpine site due to their resistance to mobilisation by meltwater percolation (Figs 1, 2). Ba, Ca, Mg, Mn, $\mathrm{Na}$ and $\mathrm{Sr}$, however, showed concentration records heavily impacted by meltwater percolation (Figs 1,2), and are therefore not recommended to be used as mineral dust proxies in cases where meltwater formation occurred.

Within the group of TEs representative of anthropogenic atmospheric pollution, $\mathrm{Cd}, \mathrm{Co}, \mathrm{Ni}$ and $\mathrm{Zn}$ were significantly depleted in the section affected by meltwater, thereby their seasonal variation could not be identified anymore (group 2 , Figs 1,2). These TEs are commonly emitted to the atmosphere due to human activities such as metallurgic processes or fuel combustion (Pacyna and Pacyna, 2001). In contrast, $\mathrm{Ag}, \mathrm{Cu}, \mathrm{Mo}, \mathrm{Pb}, \mathrm{Sb}$ and $\mathrm{V}$ exhibited an exceptional robustness regarding post-depositional melting processes (group 1 , Figs 1,2$)$. In this group, $\mathrm{Pb}$ has been extensively used as a proxy for metal smelting, mining activities, coal combustion and use of leaded gasoline in ice cores (Huo and others, 1999; McConnell and others, 2002; Schwikowski and others, 2004; Shotyk and others, 2005; Li and others, 2006; Osterberg and others, 2008; Lee and others, 2011; Eichler and others, 2012). Based on these observations, we suggest that $\mathrm{Ag}, \mathrm{Cu}, \mathrm{Mo}, \mathrm{Pb}, \mathrm{Sb}$ and $\mathrm{V}$ could still serve as tracers to reconstruct and estimate the impact of human emissions to the atmosphere (Galloway and others, 1982) from melt-affected ice core archives. However, Cd, Co, Ni and $\mathrm{Zn}$ records should be interpreted with caution due to probable meltwater mobility.

Regarding volcanism, in addition to the previously mentioned $\mathrm{Pb}$ and $\mathrm{Sb}, \mathrm{Bi}$ and $\mathrm{Tl}$ tend to be reliable proxies in melt-affected ice core records. Also, volcanic ejection material is often enriched in Cd and Zn (Nho and others, 1996), but as discussed above, the use of $\mathrm{Cd}$ and $\mathrm{Zn}$ as tracers is not recommended.

Group 1 TEs, with their pronounced and less affected seasonal concentration variability, could also serve as markers for annual layer counting to establish the chronology of ice cores affected by post-depositional melt processes.

Our study demonstrates that many TEs are still valuable environmental proxies even if partial melting occurs at high-Alpine sites. One should note that our results are not rigorously transferable to ice core archives from other locations. Our findings show that the preservation of TEs during melting is determined by their concentrations and the dust mineralogy. Both parameters are site-specific. For instance, TE concentrations in ice cores from the remote Greenland and Antarctic ice sheets (Candelone and others, 1995; Vallelonga and others, 2003) can be up to three orders of magnitude lower compared with Alpine sites. According to our findings, the low concentrations at these sites could generally favour preservation of TEs during melting. In contrast, higher TE concentrations occur in ice cores from the Tibetan Plateau, especially for mineral dust related TEs (Beaudon and others, 2017; Sierra-Hernández and others, 2018). At these sites, concentration records of (low) water- soluble mineral dust related TEs assigned to group 1 in our study could be significantly disturbed by meltwater percolation. Contrariwise, higher mineral dust loading favours the presence of water-insoluble particles, less prone to meltwater relocation.

\section{CONCLUSIONS}

The analysis of 35 TEs in a $50 \mathrm{~m}$ ice core segment from upper Grenzgletscher is presented here. This segment of the ice core comprised a $16 \mathrm{~m}$ section that consisted of firn when an inflow and percolation of meltwater occurred. The special setting of sections unaffected by meltwater above and below this melt-affected section in the studied ice core segment provided good references for characterising the TE response to post-depositional melting processes at highAlpine sites.

Some TEs revealed significant concentration depletion due to meltwater-induced relocation, whereas others were well preserved depending on their water solubility and location at the grain scale. TEs linked to insoluble particles, typically enriched at grain boundaries, were found to be mostly preserved, because their insolubility in water results in immobility with meltwater percolation. In the case of TEs present as (low) soluble compounds, variable mobility with meltwater was observed presumably due to a different microscopic location in the ice structure. We suggest that for those TEs, the concentration present is the major driving force determining their incorporation into the ice lattice or segregation to the grain surfaces. The size of the corresponding ions has a negligible effect. Further studies, preferably using direct in situ techniques, are needed to corroborate this indirect assessment of TE location in ice.

Based on their immobility with meltwater percolation, we propose that $\mathrm{Ag}$, $\mathrm{Al}, \mathrm{Bi}, \mathrm{Cu}, \mathrm{Cs}, \mathrm{Fe}, \mathrm{Li}, \mathrm{Mo}, \mathrm{Pb}, \mathrm{Rb}, \mathrm{Sb}$, Th, $\mathrm{Tl}$, $\mathrm{U}, \mathrm{V}, \mathrm{W}, \mathrm{Zr}$ and the REEs (Ce, Eu, La, Nd, Pr, Sc, Sm, Yb) may still be applicable as robust environmental proxies in ice cores from Alpine glaciers partially affected by melting. In contrast, concentration records of $\mathrm{Ba}, \mathrm{Ca}, \mathrm{Cd} \mathrm{Co}, \mathrm{Mg}, \mathrm{Mn}$, $\mathrm{Na}, \mathrm{Ni}, \mathrm{Sr}$ and $\mathrm{Zn}$ are prone to significant depletion.

Site-specific variations in TE concentrations and mineralogy are likely to modify our established classification. Thus, TE response to post-depositional melting processes may vary between remote sites and heavily polluted regions.

\section{ACKNOWLEDGEMENTS}

Funding by the Swiss National Science Foundation (SNSF, Grant No. 155999) is gratefully acknowledged. We also thank Leonhard Tobler for introducing SEA to the ICP-MS analysis and Jacinta Edebeli for improving the English of the manuscript. We greatly appreciate the detailed comments and suggestions of the two anonymous referees. They helped to improve the clarity of the manuscript.

\section{REFERENCES}

Allègre C, Manhès G and Lewin É (2001) Chemical composition of the Earth and the volatility control on planetary genetics. Earth Planet. Sci. Lett., 185(1-2), 49-69

Baltensperger $U$ and 6 others (1997) Aerosol climatology at the highalpine site Jungfraujoch, Switzerland. J. Geophys. Res. Atmos., 102(D16), 19707-19715

Barbante C and 6 others (1999) Trace element determination in alpine snow and ice by double focusing inductively coupled 
plasma mass spectrometry with microconcentric nebulization. J. Anal. At. Spectrom., 14(9), 1433-1438

Barbante $C$ and 14 others (2004) Historical record of european emissions of heavy metals to the atmosphere since the 1650s from alpine snow/lce cores drilled near Monte Rosa. Environ. Sci. Technol., 38(15), 4085-4090

Beaudon E, Gabrielli P, Sierra-Hernández MR, Wegner A and Thompson LG (2017) Central Tibetan Plateau atmospheric trace metals contamination: a 500-year record from the Puruogangri ice core. Sci. Total Environ., 601-602, 1349-1363

Birmili W, Allen AG, Bary F and Harrison RM (2006) Trace metal concentrations and water solubility in size-fractionated atmospheric particles and influence of road traffic. Environ. Sci. Technol., 40(4), 1144-1153

Candelone J-P, Hong S, Pellone C and Boutron CF (1995) PostIndustrial revolution changes in large-scale atmospheric pollution of the northern hemisphere by heavy metals as documented in central Greenland snow and ice. J. Geophys. Res., 100(D8), 16605

Correia A and 6 others (2003) Trace elements in South America aerosol during 20th century inferred from a Nevado Illiman ice core, Eastern Bolivian Andes (6350 m asl). Atmos. Chem. Phys., 3(5), 1337-1352

David F, Vokhmin V and lonova G (2001) Water characteristics depend on the ionic environment. Thermodynamics and modelisation of the aquo ions. J. Mol. Liq., 90(1-3), 45-62

Davis RE (1991) Links between snowpack physics and snowpack chemistry. In Davies TD, Tranter M, Jones HG eds. Seasonal snowpacks. Springer, Berlin Heidelberg, Berlin, Heidelberg, 115-138 (doi: 10.1007/978-3-642-75112-7_5)

Della Lunga D, Müller W, Rasmussen SO and Svensson A (2014) Location of cation impurities in NGRIP deep ice revealed by cryo-cell UV-laser-ablation ICPMS. J. Glaciol., 60(223), 970-988

Döscher A, Gäggeler HW, Schotterer U and Schwikowski M (1995) A130 years deposition record of sulfate, nitrate and chloride from a high-alpine glacier. Water, Air, Soil Pollut., 85(2), 603-609

Eichler A, Schwikowski M and Gäggeler HW (2000a) An Alpine icecore record of anthropogenic $\mathrm{HF}$ and $\mathrm{HCl}$ emissions. Geophys. Res. Lett., 27(19), 3225-3228

Eichler A and 7 others (2000b) Glaciochemical dating of an ice core from upper Grenzgletscher (4200 m a.s.I.). J. Glaciol., 46(154), 507-515

Eichler A, Schwikowski M and Gäggeler HW (2001) Meltwaterinduced relocation of chemical species in Alpine firn. Tellus $B$ Chem. Phys. Meteorol., 53(2), 192-203

Eichler A, Schwikowski $M$, Furger $M$, Schotterer $U$ and Gäggeler HW (2004) Sources and distribution of trace species in Alpine precipitation inferred from two 60-year ice core paleorecords. Atmos. Chem. Phys. Discuss., 4(1), 71-108

Eichler A and 6 others (2012) Three centuries of Eastern European and Altai lead emissions recorded in a Belukha ice core. Environ. Sci. Technol., 46(8), 4323-4330

Eichler A and 5 others (2014) Ice-core based assessment of historical anthropogenic heavy metal $(\mathrm{Cd}, \mathrm{Cu}, \mathrm{Sb}, \mathrm{Zn})$ emissions in the soviet union. Environ. Sci. Technol., 48(5), 2635-2642

Eichler A, Gramlich G, Kellerhals T, Tobler L and Schwikowski M (2015) Pb pollution from leaded gasoline in South America in the context of a 2000-year metallurgical history. Sci. Adv., 1(2), e1400196

Eichler A and 5 others (2017) Ice-core evidence of earliest extensive copper metallurgy in the Andes 2700 years ago. Sci. Rep., 7, 41855

Eyrikh S and 5 others (2017) A 320 year Ice-core record of atmospheric $\mathrm{Hg}$ pollution in the Altai, Central Asia. Environ. Sci. Technol., 51(20), 11597-11606

Gabrieli J (2008) Trace elements and polycyclic aromatic hydrocarbons (PAHs) in snow and ice sampled at Colle Gnifetti, Monte Rosa $(4450 \mathrm{~m})$, during the past 10,000 years: environmental and climatic implications. University Ca' Foscari of Venice, Italy.
Gabrieli J and 12 others (2011) Impact of Po Valley emissions on the highest glacier of the Eastern European Alps. Atmos. Chem. Phys., 11(15), 8087-8102

Gabrielli P, Cozzi G, Torcini S, Cescon P and Barbante C (2008) Trace elements in winter snow of the Dolomites (Italy): a statistical study of natural and anthropogenic contributions. Chemosphere, 72(10), 1504-1509

Gabrielli P and 7 others (2014) Deglaciated areas of Kilimanjaro as a source of volcanic trace elements deposited on the ice cap during the late Holocene. Quat. Sci. Rev., 93, 1-10

Galloway JN, Thornton JD, Norton SA, Volchok HL and McLean RAN (1982) Trace metals in atmospheric deposition: a review and assessment. Atmos. Environ., 16(7), 1677-1700

Greaves MJ, Statham PJ and Elderfield H (1994) Rare earth element mobilization from marine atmospheric dust into seawater. Mar. Chem., 46(3), 255-260

Grigholm B and 9 others (2016) Mid-twentieth century increases in anthropogenic $\mathrm{Pb}, \mathrm{Cd}$ and $\mathrm{Cu}$ in central Asia set in hemispheric perspective using Tien Shan ice core. Atmos. Environ., 131, 1728

Hobbs P V (1974) Ice physics. Oxford University Press, Oxford

Hong S and 9 others (2004) Atmospheric heavy metals in tropical South America during the past 22000 years recorded in a high altitude ice core from Sajama, Bolivia. J. Environ. Monit., 6(4), 322-326

Hsu S-C and 11 others (2010) Sources, solubility, and dry deposition of aerosol trace elements over the East China Sea. Mar. Chem., 120, 116-127

Huo W, Yao T and Li Y (1999) Increasing atmospheric pollution revealed by $\mathrm{Pb}$ record of a 7 000-m ice core. Chinese Sci. Bull., 44(14), 1309-1312

Huss $M$ and 13 others (2017) Toward mountains without permanent snow and ice. Earth's Futur., 5(5), 418-435

Itoh H, Kawamura K, Hondoh T and Mae S (1996) Molecular dynamics studies of self-interstitials in ice Ih. J. Chem. Phys., 105(6), 2408-2413

Kaspari S and 7 others (2009a) A high-resolution record of atmospheric dust composition and variability since A.D. 1650 from a Mount Everest ice core. J. Clim., 22(14), 3910-3925

Kaspari S and 7 others (2009b) Recent increases in atmospheric concentrations of Bi, U, Cs, S and Ca from a 350-year Mount Everest ice core record. J. Geophys. Res., 114, D04302

Kellerhals T and 6 others (2010) Thallium as a tracer for preindustrial volcanic eruptions in an Ice core record from Illimani, Bolivia. Environ. Sci. Technol., 44(3), 888-893

Knüsel S, Piguet DE, Schwikowski M and Gäggeler HW (2003) Accuracy of continuous ice-core trace-element analysis by inductively coupled plasma sector field mass spectrometry. Environ. Sci. Technol., 37(10), 2267-2273

Lee $\mathrm{K}$ and 7 others (2011) Isotopic signatures for natural versus anthropogenic $\mathrm{Pb}$ in high-altitude Mt. Everest ice cores during the past 800 years. Sci. Total Environ., 412-413, 194-202

Li Z, Yao T, Tian L, Xu B and Li Y (2006) Atmospheric Pb variations in Central Asia since 1955 from Muztagata ice core record, eastern Pamirs. Chinese Sci. Bull., 51(16), 1996-2000

$\mathrm{Li} \mathrm{T}$ and 5 others (2015) Concentrations and solubility of trace elements in fine particles at a mountain site, southern China: regional sources and cloud processing. Atmos. Chem. Phys., 15(15), 8987-9002

Marcott SA, Shakun JD, Clark PU and Mix AC (2013) A reconstruction of regional and global temperature for the past 11,300 years. Science, 339(6124), 1198-1201

Marcus Y (2015) lons and their properties. Ions in solution and their solvation. John Wiley \& Sons, Inc, Hoboken, NJ, 10-62

Mariani I and 6 others (2014) Temperature and precipitation signal in two Alpine ice cores over the period 1961-2001. Clim. Past, 10(3), 1093-1108

McConnell JR, Lamorey GW and Hutterli MA (2002) A 250-year high-resolution record of $\mathrm{Pb}$ flux and crustal enrichment in central Greenland. Geophys. Res. Lett., 29(23), 45-1-45-4 
Mosimann L, Weingartner E and Waldvogel A (1994) An analysis of accreted drop sizes and mass on rimed snow crystals. J. Atmos. Sci., 51(11), 1548-1558

Müller-Tautges C and 5 others (2016) Historic records of organic compounds from a high Alpine glacier: influences of biomass burning, anthropogenic emissions, and dust transport. Atmos. Chem. Phys., 16(2), 1029-1043

Nho E-Y, Le Cloarec M-F, Ardouin B and Tjetjep WS (1996) Source strength assessment of volcanic trace elements emitted from the Indonesian arc. J. Volcanol. Geotherm. Res., 74(1-2), 121-129

Nightingale ER (1959) Phenomenological theory of lon solvation. Effective radii of hydrated ions. J. Phys. Chem., 63(9), 1381-1387

Osterberg E and 10 others (2008) Ice core record of rising lead pollution in the North Pacific atmosphere. Geophys. Res. Lett., 35 (5), L05810

Pacyna JM and Pacyna EG (2001) An assessment of global and regional emissions of trace metals to the atmosphere from anthropogenic sources worldwide. Environ. Rev., 9(4), 269-298

Pavlova PA and 5 others (2015) Polychlorinated biphenyls in a temperate alpine glacier: 1 . Effect of percolating meltwater on their distribution in glacier Ice. Environ. Sci. Technol., 49(24), 14085-14091

Petrenko VF and Whitworth RW (2002) Physics of Ice. Oxford University Press, Oxford

Pinzer BR, Schneebeli M and Kaempfer TU (2012) Vapor flux and recrystallization during dry snow metamorphism under a steady temperature gradient as observed by time-lapse microtomography. Cryosphere, 6(5), 1141-1155

Pruppacher HR and Klett JD (2010) Microphysics of clouds and precipitation. Springer, Netherlands, Dordrecht

Rumble JR ed. (2017) Atomic masses and abundances. CRC handbook of chemistry and physics, 98th edn. CRC Press/Taylor \& Francis, Boca Raton, FL. 2560 pp

Schwikowski M and 11 others (2004) Post-17th-Century changes of European lead emissions recorded in high-altitude alpine snow and ice. Environ. Sci. Technol., 38(4), 957-964

Schwikowski M, Schläppi M, Santibañez P, Rivera A and Casassa G (2013) Net accumulation rates derived from ice core stable isotope records of Pío XI glacier, Southern Patagonia icefield. Cryosphere, 7(5), 1635-1644

Shotyk W and 5 others (2005) Predominance of industrial Pb in recent snow (1994-2004) and ice (1842-1996) from Devon Island, Arctic Canada. Geophys. Res. Lett., 32(21), L21814

Sierra-Hernández MR, Gabrielli P, Beaudon E, Wegner A and Thompson LG (2018) Atmospheric depositions of natural and anthropogenic trace elements on the Guliya ice cap (northwestern Tibetan Plateau) during the last 340 years. Atmos. Environ., 176, 91-102

Szyrmer W and Zawadzki I (1997) Biogenic and anthropogenic sources of Ice-forming nuclei: a review. Bull. Am. Meteorol. Soc., 78(2), 209-228

Thompson LG and 6 others (1993) "Recent warming": ice core evidence from tropical ice cores with emphasis on Central Asia. Glob. Planet. Change, 7(1-3), 145-156

Uglietti C, Gabrielli P, Cooke CA, Vallelonga P and Thompson LG (2015) Widespread pollution of the South American atmosphere predates the industrial revolution by 240 y. Proc. Natl. Acad. Sci., 112(8), 2349-2354

Vallelonga P and 5 others (2003) Lead, Ba and Bi in Antarctic Law Dome ice corresponding to the 1815 AD Tambora eruption: an assessment of emission sources using $\mathrm{Pb}$ isotopes. Earth Planet. Sci. Lett., 211(3-4), 329-341

Van de Velde K and 6 others (1999) A 200 year record of atmospheric cobalt, chromium, molybdenum, and antimony in high altitude alpine firn and ice. Environ. Sci. Technol., 33(20), 3495-3501

Van de Velde K and 8 others (2000) A two hundred years record of atmospheric cadmium, copper and zinc concentrations in high altitude snow and ice from the French-Italian Alps. Geophys. Res. Lett., 27(2), 249-252

Wagenbach D and Geis K (1989) The mineral dust record in a high altitude alpine glacier (colle gnifetti, Swiss Alps). In Leinen M, Sarnthein M eds. Paleoclimatology and paleometeorology: modern and past patterns of global atmospheric transport. Springer, Netherlands, Dordrecht, 543-564

Wolff EW (1996) Location, movement and reactions of impurities in solid Ice. Chemical exchange between the atmosphere and polar snow. Springer, Berlin Heidelberg, Berlin, Heidelberg, $541-560$

Wong GJ, Hawley RL, Lutz ER and Osterberg EC (2013) Traceelement and physical response to melt percolation in Summit (Greenland) snow. Ann. Glaciol., 54(63), 52-62

Zaromb S and Brill R (1956) Solid solutions of Ice and NH4F and their dielectric properties. J. Chem. Phys., 24(4), 895-902

Zemp M, Hoelzle M and Haeberli W (2009) Six decades of glacier mass-balance observations: a review of the worldwide monitoring network. Ann. Glaciol., 50(50), 101-111

Zhang Q, Kang S, Gabrielli P, Loewen M and Schwikowski M (2015) Vanishing high mountain glacial archives: challenges and perspectives. Environ. Sci. Technol., 49(16), 9499-9500 